\title{
Pengaruh Etos Kerja Terhadap Kinerja Karyawan PT. AE
}

\author{
Andri Hadiansyah $^{1}$, Rini Purnamasari Yanwar $^{1}$ \\ ${ }^{1}$ Program Studi Psikologi, Fakultas Psikologi dan Pendidikan, Universitas Al Azhar Indonesia, Jl \\ Sisingamangaraja Kompleks Masjid Agung Al Azhar, Jakarta, 12110
}

Penulis untuk Korespondensi/E-mail: andri hadiansyah@uai.ac.id

\begin{abstract}
Abstrak - Untuk dapat mencapai hubungan yang sinergis, perusahaan harus dapat memperhatikan pola kinerja karyawannya. Karyawan yang bermutu dan dapat menghasilkan kinerja yang tinggi adalah karyawan yang dibutuhkan oleh suatu organisasi. Peran yang sangat vital dalam mewujudkan prestasi kinerja seorang karyawan adalah dirinya sendiri. Bagaimana dia memiliki semangat dan etos kerja yang tinggi untuk dapat memberikan pengaruh positif pada lingkungannya. Karyawan yang memiliki pemikiran yang luhur mengenai pekerjaannya dapat bekerja dengan tulus. Suatu pandangan dan sikap terhadap kerja dikenal dengan istilah etos kerja. Penelitian ini bertujuan untuk melakukan uji teoritik mengenai pengaruh etos kerja terhadap kinerja karyawan PT. AE. Untuk menguji pengaruh variabel etos kerja terhadap kinerja karyawan digunakan analisis regresi linear berganda dengan menyebar 132 kuesioner pada karyawan PT. AE. Setelah dianalisis didapat hasil $R$ square 0.724 dengan signifikansi $(p<0.05)$, yang berarti etos kerja memberikan pengaruh secara signifikan terhadap kinerja karyawan sebesar $72.4 \%$.
\end{abstract}

\section{Kata Kunci: Etika Kerja, Performa Kerja}

Abstract - To be able to achieve a synergistic relationship, the company should be able to notice employee performance. Employees who are qualified and able to produce high performance is needed by the organization. A very vital role in realizing the achievement of the performance of an employee is himself. How does he have the spirit and high work ethic to be a positive influence on the environment. Employees who have lofty thoughts about the job can work sincerely. An outlook and attitude towards work is known as the work ethic. This study aims to perform a theoretical test on the effect of the work ethic on the performance of employees of PT. AE. To test the effect of variables on the performance of the employee's work ethic multiple linear regression analysis was used, by spread 132 questionnaires to employees of PT. AE. Having analyzed the results obtained R square 0.724 with 0.000 significance $(p<0.05)$, which means the work ethic significant influence on employee performance amounted to $\mathbf{7 2 . 4 \%}$. The dominant aspect of the work ethic that effect the performance is the view of work is trustworthy.

Keywords: Work ethic, Employee performance

\section{PENDAHULUAN}

Semakin berkembangnya pengetahuan
kebunusia, maka semakin banyak pula
Banyaknya kebutuhan hidup yang harus
dipenuhi mendorong seseorang untuk bekerja dan mendapatkan penghasilan dari hasil bekerja tersebut. Penghasilan yang diperoleh dapat digunakan untuk memenuhi kebutuhan pokok dan kebutuhan lain. Seseorang bekerja karena ingin mencapai kehidupan yang layak, untuk mencapai hal tersebut tentunya seseorang 
harus memiliki semangat kerja yang tinggi. Seiring dengan meningkatnya aktivitas organisasi di lingkungan global, maka setiap organisasi akan selalu berupaya menjalankan kegiatannya secara profesional untuk mencapai tujuan organisasi yang sesuai dengan visi, misi, dan strateginya.

Sumber Daya Manusia (SDM) atau karyawan merupakan salah satu dari beberapa unsur yang digunakan oleh organisasi dalam menjalankan kegiatannya. SDM bermutu harus dimiliki oleh setiap lini organisasi, karena SDM memiliki peran inti di era globalisasi ini. Perusahaan harus dapat mencari dan memelihara SDM yang mampu untuk mengimplementasikan dan mencapai keberhasilan suatu organisasi. Keberhasilan suatu perusahaan dalam mencapai tujuannya tidak hanya bergantung kepada sarana dan prasarana yang ada tetapi juga bergantung pada kinerja karyawannya.

Organisasi dapat mencari dan memelihara SDM yang mampu untuk mengimplementasikan dan mencapai keberhasilan suatu organisasi, dengan menggunakan sebuah sistem atau proses yang dapat mengelola SDM, yang biasa disebut dengan manajemen. Oleh karena itu, untuk memiliki SDM yang terbaik dan mampu berkompetisi di dunia global, maka diperlukan manajemen SDM (Dessler, 2014:4).

Untuk dapat mencapai hubungan yang sinergis, perusahaan harus dapat memperhatikan pola kinerja karyawannya. Pengertian kinerja menurut Mangkunegara (2000:67) adalah hasil kerja secara kualitas dan kuantitas yang dicapai oleh seorang karyawan dalam melaksanakan tugasnya sesuai dengan tanggung jawab yang diberikan kepadanya. Untuk meraih sukses diperlukan seperangkat sikap, kondisi mental, kemampuan psikologis, dan perilaku kerja yang prima.

Peran yang sangat vital dalam mewujudkan prestasi kinerja seorang karyawan adalah dirinya sendiri. Bagaimana dia memiliki semangat dan etos kerja yang tinggi untuk dapat memberikan pengaruh positif pada lingkungannya (Sinamo, 2011:18). Anoraga (2001:10) berpendapat bahwa keberhasilan dalam persaingan kerja tidak hanya membutuhkan keahlian dan kemampuan saja tetapi juga diperlukan adanya dedikasi, kerja keras, dan kejujuran dalam bekerja. Seseorang yang berhasil harus memiliki pandangan dan sikap yang menghargai kerja sebagai sesuatu yang luhur untuk eksistensi manusia. Karyawan yang memiliki pemikiran yang luhur mengenai pekerjaannya dapat bekerja dengan tulus. Suatu pandangan dan sikap terhadap kerja dikenal dengan istilah etos kerja.

Etos kerja merupakan sikap, pandangan, kebiasaan, ciri-ciri atau sifat mengenai cara bekerja yang dimiliki seseorang, suatu golongan atau suatu bangsa (Dodi, dkk, 2013). Etos kerja adalah semangat kerja yang terlihat dalam cara seseorang menyikapi pekerjaan, motivasi yang melatarbelakangi melakukan suatu pekerjaan (Fadillah, 2010).

Fenomena yang terjadi pada karyawan PT. $\mathrm{AE}$ ialah adanya penurunan kinerja karyawan pada tahun 2012 hingga 2014. Hal tersebut dapat terlihat dari data kinerja karyawan PT. AE. Berdasarkan data tersebut dapat terlihat bahwa terjadi penurunan kinerja pada karyawan PT. AE selama tiga tahun terakhir. Kinerja karyawan PT. AE pada tahun 2012 sebesar 67.6\%, pada tahun 2013 sebesar $62.2 \%$, dan pada tahun 2014 sebesar 33.9\%. Terjadi penurunan kinerja dari tahun 2012 ke 2013 sebesar 5.4\%. Sedangkan terjadi penurunan kinerja sebesar $28.3 \%$ dari tahun 2013 ke 2014. Berdasarkan standarisasi PT. AE, kinerja karyawan dapat dikatakan menurun apabila terjadi penurunan $\geq 10 \%$. Dengan kata lain, kinerja karyawan PT. AE tidak optimal dan megalami penurunan, karena selama tiga tahun terakhir terus mengalami penurunan dan pada tahun $2013 \mathrm{ke}$ 2014 mencapai angka $28.3 \%$.

Berdasarkan dari berbagai penjelasan tersebut, maka dapat disimpulkan bahwa etos kerja merupakan hal penting yang perlu diperhatikan lebih lanjut untuk mendapatkan kinerja karyawan yang tinggi. Sehubungan dengan beberapa hal dan fenomena di atas, maka penelitian berikutnya memfokuskan pada pengaruh etos kerja terhadap kinerja karyawan. Dengan demikian judul penelitian ini ialah "Pengaruh Etos Kerja terhadap Kinerja Karyawan PT AE". 
Tujuan penelitian yang ingin dicapai pada penelitian ini ialah untuk melakukan uji teoritik mengenai pengaruh etos kerja terhadap kinerja karyawan PT. AE.

\section{TINJAUAN PUSTAKA}

\section{Kinerja Karyawan}

Kinerja karyawan ialah hasil kerja secara kualitas dan kuantitas yang dicapai oleh seorang karyawan dalam melaksanakan tugasnya sesuai dengan tanggung jawab yang diberikan kepadanya berdasarkan persyaratan pekerjaan, yang mencakup perilaku yang berasal dari diri sendiri yaitu usaha secara mental (pemikiran) dan fisik, yang bisa dinilai terpisah dari hasil kerja.

Bernardin dan Russel (1993:383) menjelaskan, terdapat enam dimensi dalam menilai kinerja karyawan, yaitu:

a. Quality (Kualitas)

Sejauh mana proses atau hasil dalam melakukan kegiatan dengan cara yang ideal, sesuai dengan cara yang ideal dalam melakukan aktivitas atau kegiatan yang memenuhi tujuan yang dimaksud.

b. Quantity (Kuantitas)

Jumlah yang dihasilkan, diwujudkan melalui nilai mata uang, jumlah unit, atau jumlah dari siklus aktifitas yang telah diselesaikan.

c. Timeliness (Ketepatan Waktu)

Tingkatan di mana aktifitas telah diselesaikan, atau hasil yang telah diproduksi, dengan waktu yang lebih cepat dari yang ditentukan dan memaksimalkan waktu yang ada untuk aktifitas lain.

\section{d. Cost Effectiveness (Efektivitas Biaya)}

Tingkatan dimana penggunaan sumber daya perusahaan berupa manusia, keuangan, teknologi, dan material dimaksimalkan untuk mendapatkan hasil dan keuntungan yang tertinggi atau pengurangan kerugian dari tiap unit yang ada.

e. Need for Supervision (Perlu Pengawasan) Tingkatan dimana seorang karyawan dapat melakukan fungsi pekerjaannya tanpa perlu meminta pertolongan atau intervensi dari atasannyauntuk mencegah hasil yang merugikan.

\section{f. Interpersonal Impact (Dampak Interpersonal)}

Tingkatan dimana seorang karyawan merasa percaya diri, punya keinginan yang baik, dan bekerja sama antar rekan kerja dan bawahan. Menurut Wirawan (2009:6), kinerja karyawan merupakan hasil sinergi dari sejumlah faktor.

Faktor-faktor tersebut ialah:

a. Faktor internal karyawan, yaitu faktor-faktor dari dalam diri karyawan yang merupakan faktor bawaan dari lahir dan faktor yang diperoleh ketika individu berkembang.

b. Faktor-faktor lingkungan internal organisasi.

Dalam melaksanakan tugasnya, karyawan memerlukan dukungan organisasi tempatnya bekerja.

c. Faktor lingkungan eksternal organisasi.

Faktor- faktor lingkungan eksternal organisasi adalah keadaan, kejadian, atau situasi yang terjadi di lingkungan eksternal organisasi yang mempengaruhi kinerja karyawan.

\section{Etos Kerja}

Menurut Sinamo (2011:35), etos kerja adalah

seperangkat perilaku kerja positif dan bermutu tinggi, yang berakar pada kesadaran yang jernih dan keyakinan yang kuat pada paradigma kerja yang holistik. Istilah paradigma di sini berarti konsep utama tentang kerja itu sendiri yang mencakup idealisme yang mendasarinya, prinsip-prinsip yang mengaturnya, nilai-nilai luhur yang menggerakkannya, sikap-sikap mulia yang dilahirkannya, dan standar-standar tinggi yang hendak dicapainya termasuk karakter utama, pikiran pokok, kode etik, kode moral, dan kode perilaku para pemeluknya.

Sinamo (2011) menjelaskan, terdapat delapan aspek etos kerja yang sudah terbukti secara universal diterima dan dipercaya. Aspek-aspek tersebut ialah kerja adalah rahmat, kerja adalah amanah, kerja adalah panggilan, kerja adalah aktualisasi, kerja adalah ibadah, kerja adalah seni, kerja adalah kehormatan, dan kerja adalah pelayanan. 


\section{Kerangka Berpikir}

Kerangka berpikir yang dikembangkan dalam penelitian ini dapat digambarkan dalam model penelitian sebagai berikut:

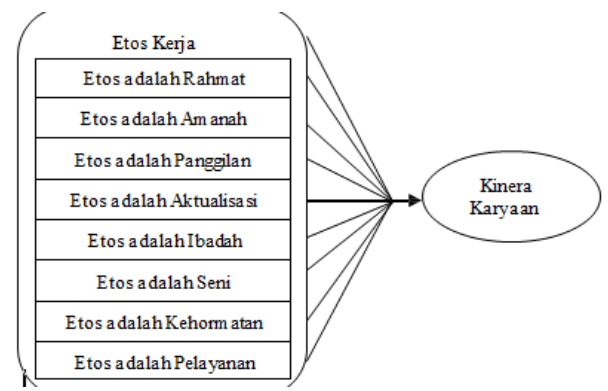

Gambar 1. Model Teoritik

\section{METODOLOGI PENELITIAN}

\section{Jenis Penelitian}

Jenis penelitian ini ialah penelitian terapan.

Penelitian terapan (applied research, practical research) adalah penyelidikan yang hati-hati, sistematik dan terus-menerus terhadap suatu masalah dengan tujuan untuk digunakan dengan segera untuk keperluan tertentu. Hasil penelitian tidak perlu sebagai suatu penemuan baru, tapi merupakan aplikasi baru dari penelitian yang telah ada (Nazir, 2009:26). Penelitian ini merupakan penelitian survey dengan menggunakan pendekatan kuantitatif.

\section{Tempat dan Waktu Penelitian}

Penelitian ini dilaksanakan di PT. AE, dikarenakan sesuai dengan fenomena yang terjadi. Kegiatan ini dilaksanakan pada bulan Mei - Agustus 2015.

\section{Variabel Penelitian}

Variabel dalam penelitian ini meliputi dua jenis variabel penelitian, yaitu variabel bebas dan variabel terikat. Adapun kedua variabel tersebut dalam penelitian ini adalah:
1. Variabel Terikat : Kinerja
Karyawan
2. Variabel Bebas : Etos Kerja

\section{Definisi Konseptual dan Definisi Operasional Variabel Penelitian \\ Adapun definisi operasional dan definisi konseptual penelitian selengkapnya ialah sebagai berikut: \\ 1. Kinerja Karyawan}

Definisi kinerja karyawan yang digunakan pada penelitian ini ialah kerja secara kualitas dan kuantitas yang dicapai oleh seorang karyawan dalam melaksanakan tugasnya sesuai dengan tanggung jawab yang diberikan kepadanya berdasarkan persyaratan pekerjaan, yangmencakup perilaku yang berasal dari diri sendiri yaitu usaha secara mental (pemikiran) dan fisik, yang bisa dinilai terpisah dari hasil kerja. Variabel kinerja karyawan disusun dengan menggunakan Skala Likert yang terdiri dari lima alternatif jawaban. Menggunakan enam dimensi dari Bernardin Russel (1993:383) yaitu quality, quantity, timeliness, cost effectiveness, need for supervision, dan interpersonal impact.

\section{Etos Kerja}

Definisi etos kerja yang digunakan pada penelitian ini ialah etos kerja merupakan pandangan mengenai cara bekerja yang dimiliki seseorang, suatu golongan atau suatu bangsa, berisikan sistem nilai yang menyangkut persepsi individu dalam melaksanakan pekerjaannya. Variabel etos kerja disusun dengan menggunakan Skala Likert yang terdiri dari lima alternatif jawaban. Menggunakan delapan aspek etos kerja dari Sinamo (2011). Aspek-aspek tersebut ialah kerja adalah rahmat, kerja adalah amanah, kerja adalah panggilan, kerja adalah aktualisasi, kerja adalah ibadah, kerja adalah seni, kerja adalah kehormatan, dan kerja adalah pelayanan.

\section{Metode Analisis Data}

Metode analisis data yang digunakan dalam penelitian ini adalah regresi linier berganda. Menurut Priyatno (2008:73) pengertian analisis regresi linier berganda adalah hubungan secara linear antara dua atau lebih variabel independen $\left(\mathrm{X}_{1}, \mathrm{X}_{2}, \ldots ., \mathrm{X}_{\mathrm{n}}\right)$ dengan variabel dependen $(\mathrm{Y})$

\section{HASIL PENELITIAN DAN PEMBAHASAN}

\section{Gambaran Umum Perusahaan}

PT. AE merupakan produsen fabrikasi dan ekstrusi profil aluminum terkemuka di Indonesia dengan berbagai fasilitas manufaktur untuk ekstrusi aluminium, fabrikasi, clear anodisasi, anodisasi warna dan powder coating. PT. AE juga memiliki 
tim manajemen dengan visi dan misi ke depan untuk mencapai keunggulan terbaik dalam pemenuhan

kebutuhan dan keinginan pasar yang melebihi harapan para pelanggan yang dilayaninya. Produk PT. AE telah banyak dipergunakan di gedung- gedung bertingkat di Jakarta maupun di seluruh Indonesia, baik untuk kerangka pintu dan jendela di hotel, perkantoran, pertokoan, dan lain-lain, serta diberbagai industri transportasi, energi, elektronik, perkapalan, serta berbagai keperluan rumah tangga.

\section{Gambaran Umum Responden}

Berdasarkan data dari 132 responden yang bekerja di PT. AE, melalui daftar pernyataan didapat kondisi responden tentang jenis kelamin, lama bekerja, pendidikan terakhir dan jabatan kerja.

Berdasarkan hasil penelitian diperoleh gambaran mengenai jenis kelamin, responden dengan jenis kelamin laki-laki lebih banyak dibandingkan responden dengan jenis kelamin perempuan. Responden dengan jenis kelamin laki-laki sebanyak $84 \%$ dan responden dengan jenis kelamin perempuan sebanyak $16 \%$. Jika dilihat dari pendidikan terakhir dari responden, didapat responden dengan beragam jenis pendidikan. Responden terbanyak dengan jumlah $69 \%$ memiliki pendidikan terakhir yaitu SMA/SMK/SLTA/STM. Diikuti dengan pendidikan Strata 1 dengan jumlah $21 \%$, pendidikan D3 dengan jumlah 9\% dan terdapat $1 \%$ responden yang memiliki pendidikan terakhir SMP.

Dapat diperoleh pula lama bekerja para responden. Responden yang bekerja dibawah 5 tahun memiliki jumlah terbanyak dengan $42 \%$, diikuti dengan responden yang lama bekerja lebih dari 15 tahun sebanyak $31 \%$, dan responden dengan lama bekerja lebih 5 - 15 tahun sebanyak $27 \%$.

Terdapat delapan divisi di PT. AE dengan jumlah responden yang berbeda-beda. Responden yang dipilih mewakili dari setiap divisi yang ada di PT. AE. Responden paling banyak diwakili oleh divisi produksi sejumlah $63 \%$, diikuti oleh divisi keuangan dan akuntan dengan jumlah $18 \%$, kemudian divisi umum dan personalia berjumlah $14 \%$, dan divisi pemasaran berjumlah $5 \%$.

\section{Uji Normalitas}

Data penelitian yang dilakukan memiliki distribusi yang normal. Uji normalitas dikerjakan menggunakan SPSS 20.0 for windows. Adapun hasil yang didapat ialah sebagai berikut:

Tabel 1. Uji Normalitas Kolmogorov-Smirnov

One-Sample Kolmogorov-Smirnov Test

\begin{tabular}{|ll|r|}
\hline & & $\begin{array}{c}\text { Unstandardized } \\
\text { Residual }\end{array}$ \\
\hline Normal & Mean & 132 \\
& &, 0000000 \\
Most Extreme & Absolute & \\
Dinterences & Positive & .078 \\
Kolmogorov-Smirnov Z & .053 \\
Asymp. Sig. (2-tailed) & -.078 \\
\end{tabular}

a. Test distribution is Normal.

b. Calculated from data.

Berdasarkan tabel di atas, diketahui bahwa nilai signifikansi sebesar 0.394 lebih besar dari 0.05 , sehingga dapat disimpulkan bahwa data yang diuji berdistribusi normal.

\section{Uji Linearitas}

Data penelitian yang dilakukan terdapat hubungan yang linear. Uji Linearitas dikerjakan menggunakan SPSS 20.0 for windows. Adapun hasil yang didapat ialah sebagai berikut:

Tabel 4. 2 Uji Linearitas

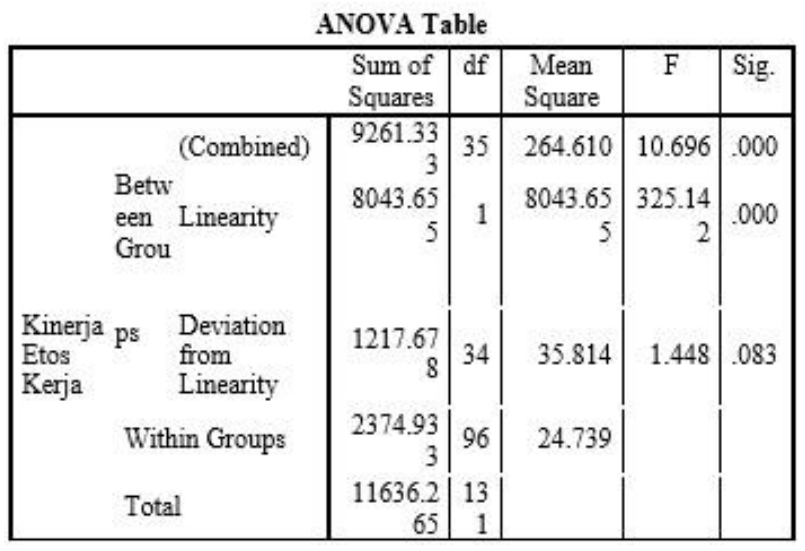

Dari tabel di atas dapat diketahui bahwa nilai signifikansi pada Linearity sebesar 0.000 , artinya signifikansi kurang dari 0.05 . 
Maka dapat disimpulkan bahwa antara variabel etos kerja dan kinerja karyawan terdapat hubungan yang linear.

\section{Uji}

\section{Multikolinearitas}

Data penelitian yang dilakukan tidak terjadipersoalan multikolinearitas. Uji Multikolinearitas dikerjakan menggunakan SPSS 20.0 for windows. Adapun hasil yang didapat ialah sebagai berikut:

Tabel 4. 3 Uji Multikolinearitas

Coefficients ${ }^{\mathrm{a}}$

\begin{tabular}{|ll|r|r|}
\hline Model & & \multicolumn{2}{|c|}{$\begin{array}{c}\text { Collinearity Statistics } \\
\text { Tolerance }\end{array}$} \\
\cline { 4 - 4 } & & VIF \\
\hline 1 & $\begin{array}{l}\text { (Constant) } \\
\text { EtosKerja }\end{array}$ & 1.000 & 1.000 \\
\hline
\end{tabular}

a. Dependent Variable: Kinerja

Dari tabel di atas dapat dikethaui nilai Variance Inflation Factor (VIF) adalah 1.000 lebih kecil dari 5, sehingga bisa diduga bahwa antarvariabel independen tidak terjadi persoalan multikolinearitas.

\section{Analisis Hasil Penelitian}

Hasil penelitian menunjukkan beberapa hal yang dapat didiskusikan dan dianalisis oleh peneliti. Dari 132 orang responden yang merupakan karyawan PT. AE, peneliti mendapatkan data tambahan atau demografi dari karyawan PT. AE.

Penelitian ini khusus mengamati mengenai bagaimana pengaruh etos kerja terhadap kinerja karyawan, dengan objek penelitian yang berbeda dengan penelitian-penelitian terdahulu. Penelitian ini lebih berfokus pada faktor psikologis dari tiap individu yang berpengaruh pada efektifitas kinerja organisasi yaitu etos kerja para karyawan PT. AE. Penelitian ini menggunakan aspek-aspek yang berbeda dibandingkan penelitian terdahulu lainnya. Berdasarkan aspek-aspek tersebut pengaruh yang didapatkan pada penelitian lebih besar dibandingkan penelitian terdahulu.

Berdasarkan dari analisa data hasil perhitungan yang diperoleh menunjukan bahwa terdapat pengaruh yang signifikan antara etos kerja terhadap kinerja karyawan PT. AE. Hal ini dapat dilihat dimana nilai $\mathrm{r}_{\text {hitung }}(0.851)>\mathrm{r}_{\text {tabel }}(0.171), \mathrm{p}$ value 0.000 < 0.05 dan nilai $\mathrm{R}$ Square diperoleh nilai sebesar 0.724 atau $72.4 \%$. Ini berarti etos kerja memberikan kontribusi sebesar $72.4 \%$ terhadap kinerja karyawan PT. AE, sedangkan sisanya sebanyak $27.6 \%$ dipengaruhi oleh faktor lain yang tidak diteliti pada penelitian ini. Hal ini menunjukan bahwa semakin naik variabel etos kerja karyawan maka semakin meningkat kinerjanya.

Seperti yang dinyatakan oleh Wirawan (2009:6), terdapat tiga faktor yang mempengaruhi kinerja, yaitu faktor internal karyawan, faktor lingkungan internal organisasi, dan faktor lingkungan eksternal. Faktor- faktor internal karyawan bersinergi dengan faktor- faktor lingkungan internal organisasi dan faktor- faktor lingkungan eksternal organisasi. Sinergi ini mempengaruhi perilaku kerja karyawan seperti etos kerja, disiplin kerja, motivasi kerja, dan lain sebagainya yang kemudian mempengaruhi kinerja karyawan.

Hasil penelitian menunjukan bahwa aspek kerja adalah amanah merupakan aspek yang paling dominan mempengaruhi kinerja karyawan PT. AE. Dengan koefisien regresi sebesar 0.526 dengan signifikansi sebesar 0.000 ( $\mathrm{p}<0.05$ ). Artinya aspek kerja adalah amanah secara positif dan signifikan mempengaruhi kinerja karyawan PT. AE. Apabila pandangan kerja adalah amanah kurang sesuai, maka akan terjadi penurunan kinerja karyawan. Menurut Sinamo (2011), amanah adalah titipan berharga yang dipercayakan kepada seseorang. Amanah melahirkan tanggung jawab. Suatu tanggung jawab harus ditunaikan secara baik dan benar. Kesadaran amanah melahirkan kewajiban moral, sehingga tumbuh perasaan bahwa nilai itu harus dijaga sebaik- baiknya. Kewajiban moral inilah yang disebut tanggung jawab. Kerja adalah amanah, jabatan adalah amanah. Pandangan sebagai pemegang amanah adalah orang yang dipercayai dan diharapkan mampu menunaikan amanah tersebut dengan sukses, akan membuat sesorang dipercayai secara teknis dan secara moral. Seseorang yang dipercayai secara teknis mengandalkan kompetensi yang dimilikinya. Dengan kompetensi orang mampu melaksanakan tugasnya dengan benar sesuai standar teknis profesional. Seseorang yang 
memegang kepercayaan seseorang akan bekerja dengan integritas, dengan integritas orang mampu melaksanakan tugasnya dengan benar sesuai standar etis dan moral. Jadi kompetensi dan integritas adalah sepasang kualitas utama agar seseorang mampu mengemban amanah dengan sukses dan memiliki kinerja yang baik.

Selain aspek kerja adalah amanah, masih terdapat enam aspek lainnya yang menunjukan hasil yang signifikan memiliki pengaruh terhadap kinerja karyawan, yaitu kerja adalah rahmat, kerja adalah aktualisasi, kerja adalah ibadah, kerja adalah seni, kerja adalah kehormatan, dan kerja adalah pelayanan. Namun, hasil penelitian menunjukkan bahwa salah satu aspek yaitu kerja adalah panggilan tidak memiliki pengaruh terhadap kinerja karyawan PT. AE.

Hal ini menunjukan bahwa etos kerja berpengaruh terhadap kinerja karyawan, seperti pendapat Anoraga (2001) bahwa keberhasilan dalam persaingan kerja tidak hanya membutuhkan keahlian dan kemampuan saja tetapi juga diperlukan adanya dedikasi, kerja keras, dan kejujuran dalam bekerja. Seseorang yang berhasil harus memiliki pandangan dan sikap yang menghargai kerja sebagai sesuatu yang luhur untuk eksistensi manusia. Karyawan yang memiliki pemikiran yang luhur mengenai pekerjaannya dapat bekerja dengan tulus. Suatu pandangan dan sikap terhadap kerja dikenal dengan istilah etos kerja.

\section{KESIMPULAN DAN SARAN}

\section{Kesimpulan}

Berdasarkan hasil penelitian dan pengolahan data yang dilakukan oleh peneliti, dapat disimpulkan bahwa etos kerja memiliki pengaruh yang signifikan terhadap kinerja karyawan PT. AE dengan kontribusi delapan aspek etos kerja.

Dilihat dari perolehan nila $\mathrm{R}$ square, besarnya pengaruh aspek kerja adalah rahmat $\left(\mathrm{X}_{1}\right)$, kerja adalah amanah $\left(\mathrm{X}_{2}\right)$, kerja adalah panggilan $\left(\mathrm{X}_{3}\right)$, kerja adalah aktualisasi $\left(\mathrm{X}_{4}\right)$, kerja adalah ibadah $\left(\mathrm{X}_{5}\right)$, kerja adalah seni $\left(\mathrm{X}_{6}\right)$, kerja adalah kehormatan $\left(\mathrm{X}_{7}\right)$, dan kerja adalah pelayanan $\left(\mathrm{X}_{8}\right)$ terhadap kinerja karyawan (Y) adalah sebesar 0.724 atau
72.4\%. Artinya bahwa perubahan variabel kinerja karyawan akan dijelaskan oleh kedelapan aspek tersebut sebesar $72.4 \%$.

Berdasarkan perhitungan statistik yang dilakukan, terdapat tujuh aspek yang berpengaruh secara signifikan terhadap kinerja karyawan PT. AE. Aspek kerja adalah rahmat, kerja adalah aktualisasi, kerja adalah ibadah, kerja adalah seni, kerja adalah kehormatan, dan kerja adalah pelayanan memberikan pengaruh secara signifikan terhadapa kinerja karyawan, namun tidak dominan. Aspek kerja adalah amanah berpengaruh secara signifikan terhadap kinerja karyawan PT. AE dan merupakan aspek yang paling dominan. Pandangan kerja adalah amanah ialah kepercayaan karyawan bahwa pekerjaan adalah titipan berharga dari orang lain yang harus terus dijaga dengan baik dan bertanggung jawab atas pekerjaan tersebut.

Sedangkan hasil perhitungan statistik pada aspek "kerja adalah panggilan" tidak berpengaruh secara signifikan terhadap kinerja karyawan PT. AE. Setiap orang pasti dilengkapi dengan potensi dan kompetensi untuk menunaikan panggilan jiwanya.

Bila pekerjaannya sesuai dengan panggilan jiwanya, karyawan tersebut akan memiliki kinerja yang baik. Maka dapat disimpulkan bahwa para karyawan PT. AE bekerja bukan dikarenakan panggilan jiwanya, tetapi karena berbagai aspek lain dari etos kerja.

\section{Saran}

Berdasarkan hasil penelitian dan kesimpulan diatas, maka peneliti perlu memberikan beberapa saran, antara lain:

\section{Saran Teoritis}

Penelitian ini dapat dimanfaatkan sebagai rujukan dalam melakukan penelitian berikutnya terutama mengenai etos kerja terhadap kinerja karyawan dengan mengembangkan variabel yang lebih luas, dan bisa menambahkan faktor lainnya yang dapat mempengaruhi kinerja karyawan, seperti kompensasi, disiplin kerja, stress kerja, motivasi kerja dan lain sebagainya.

2. SaranPraktis

a. Berdasarkan hasil analisis, menunjukkan bahwa aspek kerja adalah amanah memiliki pengaruh yang 
dominan terhadap kinerja karyawan PT. AE, maka diharapkan untuk memperhatikan dan mengembangkan aspek-aspek etos kerja yang lain agar dapat terus meningkatkan pandangan dan sikap yang positif mengenai pekerjaannya dan kinerja karyawan dapat terus meningkat.

b. Untuk perusahaan, diharapkan untuk dapat meningkatkan pandangan kerja para karyawan dengan berbagai cara, seperti melaksanakan pelatihan, membuat berbagai slogan mengenai etos kerja di berbagai tempat di perusahaan agar dapat meningkatkan motivasi karyawan untuk bekerja.

c. Untuk para karyawan PT. AE, selanjutnya diharapkan untuk teteap mempertahankan dan mengembangkan pandangan kerja yang positif, seperti dengan terus mempercayai bahwa seseorang yang bekerja perlu untuk terus bertanggung jawab atas tugas yang diberikan kepadanya, yakin bahwa harus mensyukuri apa yang telah dimiliki.

\section{DAFTAR PUSTAKA}

[1] Anoraga, Pandji. 2001. Psikologi Kerja. Jakarta: Penerbit Rineka Cipta. 2006

[2] Arikunto S. 2006. Prosedur Penelitian Suatu Pendekatan Praktik, Ed Revisi VI, Penerbit PT Rineka Cipta, Jakarta.

[3] Armstrong, M., \& Taylor, S. 2014. Armstrong's handbook of human resource management practice. Kogan Page Publishers.

[4] Azwar, Saifuddin. 2012. Penyusunan Skala Psikologi. Yogyakarta: Pustaka Pelajar.

[5] Azwar, Saifuddin. 2013. Dasar-dasar Psikometri.Yogyakarta: Pustaka Pelajar.

[6] Baddu, Irwan. 2007. Pengaruh Etos Kerja Islami terhadap Kinerja Karyawan. Tesis. Malang: Universitas Brawijaya.

[7] Bangun, Wilson. 2012. Manajemen Sumber Daya Manusia. Jakarta: Penerbit Erlangga.

[8] Bernardin, H. J. dan Russel, Joyce E. A. 1993. Human Resource Management: an experiential approach. United States of
America: McGraw-Hill.

[9] Bungin, H. M. Burhan. 2011. Metodologi Penelitian Kuantitatif: Komunikasi, Ekonomi, dan Kebijakan Publik serta Ilmu-ilmu Sosial Lainnya. Jajarta: Kencana.

[10] Dessler. 2014. Manajemen Sumber Daya Manusia. Jakarta: PT Indeks

[11] Dodi, dkk. 2013. Pengaruh Iklim Organisasi, Etos Kerja dan Disiplin terhadap Kinerja Karyawan serta Dampaknya pada Kinerja PT. Arun NGL Lhokseumawe Aceh. Jurnal Manajemen. Volume 2, No 1. pp 98 - 107. Aceh: Universitas Syiah Kuala.

[12] Fadillah, Candra. 2010. Tingkat Pendapatan dan Pengaruhnya terhadap Etos Kerja Guru dalam Mengajar. Tesis. Jakarta: UIN Syarif Hidayatullah.

[13] Fajriani, dkk. 2013. Jurnal Pengaruh Gaya Kepemimpinan Kepala Sekolah dan Etos Kerja Guru terhadap Kinerja Guru. Vol 1 No 1. pp 1 - 11. Surakarta: FKIP Universitas Sebelas Maret.

[14] Gaffar, Hulaifah. 2012. Pengaruh Stres Kerja terhadap Kinerja Karyawan pada PT. Bank Mandiri (PERSERO) TBK Kantor Wilayah $X$ Makassar. Skripsi. Makassar: Universitas Hasanuddin.

[15] Hadi,Sutrisno.2000. Metodologi Research. Yogyakarta: Penerbit Andi.

[16] Krisnamurti, Inggri. 2012. Pengaruh Etos Kerja terhadap Produktivitas Pegawai Dinas Koperasi UKM Perindustrian dan Perdagangan Indramayu. Tesis. Bandung: Universitas Widyatama.

[17] Mangkunegara, Anwar Prabu. 2000. Manajemen Sumber Daya Manusia Perusahaan. Bandung: PT Remaja Rosdakarya.

[18] Mangkunegara, Anwar Prabu. 2005. Perencanaan dan Pengembangan Sumberdaya Manusia.

[19] Bandung: PT Refika Aditama. Mangkunegara, Anwar Prabu. 2014. Evaluasi Kinerja SDM. Bandung PT Refika Aditama.

[20] Margono. 2010. Metodologi Penelitian Pendidikan. Jakarta: Rineka Cipta.

[21] Nawawi, H. 2006. Evaluasi dan Manajemen Kinerja di Lingkungan Perusahaan dan Industri. Yogyakarta: Gadjah Mada University Press.

[22] Nazir, Moh. 2009. Metode Penelitian. 
Bogor: Ghalia Indonesia.

[23] Neuman, W.L. 2006. Social Research Methods:Qualitative and Quantitative Approach. USA: University of Wisconsin.

[24] Nursalam. 2003. Konsep Dan Penerapan Metodologi Penelitian Ilmu Keperawatan. Jakarta: Salemba Medika.

[25] Octarina, Arischa. 2013. Jurnal Pengaruh Etos Kerja dan Disiplin Kerja terhadap Kinerja Pegawai pada Dinas Kebudayaan Pariwisata Pemuda dan Olahraga Kabupaten Sarolangun.Sumatera: Universitas Andalas.

[26] Priyatno, Duwi. 2008. Mandiri Belajar SPSS: Untuk Analisis Data dan Uji Statistik. Yogyakarta: MediaKom.

[27] Probowati, Anna. 2005. Membangun Sikap dan Etos Kerja. Purworejo: STIE Rajawali Purworejo.

[28] Ruseffendi, E.T. (1994). Dasar-dasar Penelitian dan Bidang Non-eksakta Lainnya. Semarang: IKIP Semarang Press.

[29] Sandhi, Arief S. 2013. Analisis Pengaruh Motivasi Kerja, Lingkungan Kerja, dan Stres Kerja terhadap Kinerja Karyawan.Skripsi. Semarang: Universitas Diponegoro.

[30] Simamora. 1995. Manajemen Sumber Daya Manusia. Yogyakarta: STIE YPKN.

[31] Sinamo, Jansen. 2011. 8 Etos Kerja
Profesional. Jakarta: Institut Darma Mahardika. Sugiarto., et al. (2006). Metode Statistika: Untuk Bisnis dan Ekonomi. Jakarta: PT. Gramedia Pustaka Utama.

[32] Sugiyono. 2004. Metode Penelitian Bisnis. Cetakan keenam. Bandung: Alfabeta.

[33] Sugiyono. 2005. Metode Penelitian Administrasi. Bandung: Alfabeta.

[34] Sugiyono. 2010. Metode Penelitian Kuantitatif, Kualitatif dan $R \& D$. Bandung: Alfabeta.

[35] Sukmadinata, N, S. 2011. Metode Penelitian Pendidikan. Bandung: PT Remana

[36] Rosdakarya.Sutrisno, Edy. 2011. Manajemen Sumber Daya Manusia. Jakarta: Kencana.

[37] Umar, H. 1998. Metode Penelitian, Jakarta: Raja Grafindo Persada.

[38] Umi, N. (2008). Metodologi Penelitian Kualitatif dan Kuantitatif: Teori dan Aplikasi. Bandung.

[39] Wirawan. 2009. Evaluasi Kinerja Sumber Daya Manusia: Teori Aplikasi dan Penelitian. Jakarta: Salemba Empat.

[40] Zulham, Muhammad. 2008. Analisis Pengaruh Budaya Organisasi dan Etos Kerja terhadap Kinerja Pegawai Fakultas Ekonomi Universitas Sumatera Utara Medan. Tesis. Medan: Universitas Sumatera Utara 